Research Paper

\title{
Attenuation of Oxidative Stress-Induced Cell Apoptosis in Schwann RSC96 Cells by Ocimum Gratissimum Aqueous Extract
}

\author{
Pei-Yu Chao ${ }^{1 *}$, James A. Lin ${ }^{*}$, Je-Chiuan Ye2, Jin-Ming Hwang 3 , Wei-Jen Ting1, Chih-Yang Huang1,4,5凶, \\ Jer-Yuh Liu6,7凶 \\ 1. Graduate Institute of Basic Medical Science, China Medical University, Taichung, Taiwan \\ 2. Bachelor Program of Senior Services, Southern Taiwan University of Science and Technology, Tainan, Taiwan; \\ 3. Department of Medical Applied Chemistry, College of Health Care and Management, Chung Shan Medical University, Taichung, Taiwan \\ 4. Graduate Institute of Chinese Medical Science, School of Chinese Medicine, China Medical University, Taichung, Taiwan: \\ 5. Department of Health and Nutrition Biotechnology, Asia University, Taichung, Taiwan; \\ 6. Graduate Institute of Biomedical Sciences, China Medical University, Taichung, Taiwan \\ 7. Center for Molecular Medicine, China Medical University Hospital, Taichung, Taiwan. \\ * These authors contributed equally to this work
}

$\triangle$ Corresponding authors: Jer-Yuh Liu PhD., Graduate Institute of Biomedical Sciences, College of Medical, China Medical University, No 6, Hsueh-Shih Road, Taichung 404, Taiwan. Tel: +886-4-22052121 ext 7932; Fax: +886-4-22347028. E-mail: jyl@mail.cmu.edu.tw Chih-Yang Huang, Graduate Institute of Basic Medical Science, China Medical University, No 91, Hsueh-Shih Road, Taichung 404, Taiwan. Tel.: +886 422053366 ext 3313; Fax: +886 4 22333641. E-mail: cyhuang@mail.cmu.edu.tw

(c) Ivyspring International Publisher. This is an open access article distributed under the terms of the Creative Commons Attribution (CC BY-NC) license (https://creativecommons.org/licenses/by-nc/4.0/). See http://ivyspring.com/terms for full terms and conditions.

Received: 2017.02.07; Accepted: 2017.06.18; Published: 2017.07.18

\begin{abstract}
Objectives: Cell transplantation therapy of Schwann cells (SCs) is a promising therapeutic strategy after spinal cord injury. However, challenges such as oxidative stress hinder satisfactory cell viability and intervention for enhancing SCs survival is critical throughout the transplantation procedures. Ocimum gratissimum, widely used as a folk medicine in many countries, has therapeutic and anti-oxidative properties and may protect SCs survival.

Methods: We examined the protective effects of aqueous $O$. gratissimum extract (OGE) against cell damage caused by $\mathrm{H}_{2} \mathrm{O}_{2}$-induced oxidative stress in RSC 96 Schwann cells.

Results: Our results showed that the $\mathrm{RSC} 96$ cells, damaged by $\mathrm{H}_{2} \mathrm{O}_{2}$ oxidative stress, decreased their viability up to $32 \%$ after treatment with different concentrations of up to $300 \mu \mathrm{M} \mathrm{H}_{2} \mathrm{O}_{2}$, but OGE pretreatment $(150$ or $200 \mu \mathrm{g} / \mathrm{mL}$ ) increased cell viability by approximately $62 \%$ or $66 \%$, respectively. Cell cycle analysis indicated a high (43\%) sub-G1 cell population in the $\mathrm{H}_{2} \mathrm{O}_{2}$-treated $\mathrm{RSC} 96$ cells compared with untreated cells $(1 \%)$; whereas OGE pretreatment ( 150 and $200 \mu \mathrm{g} / \mathrm{mL})$ of RSC96 cells significantly reduced the sub-G1 cells $(7 \%$ and $8 \%$, respectively). Furthermore, Western blot analysis revealed that OGE pretreatment inhibited $\mathrm{H}_{2} \mathrm{O}_{2}$-induced apoptotic protein caspase-3 activation and PARP cleavage, as well as it reversed Bax up-regulation and $\mathrm{Bcl}-2$ down-regulation. The amelioration of OGE of cell stress and stress-induced apoptosis was proved by the HSP70 and HSP72 decrease.
\end{abstract}

Conclusion: Our data suggest that OGE may minimize the cytotoxic effects of $\mathrm{H}_{2} \mathrm{O}_{2}$-induced $\mathrm{SC}$ apoptosis by modulating the apoptotic pathway and could potentially supplement cell transplantation therapy.

Key words: Ocimum gratissimum; Schwann cells; oxidative stress, apoptosis.

\section{Introduction}

Schwann cells (SCs), the myelinating glia of the peripheral nervous system, ensheath individual axons, promote axonal growth and maintain normal electric conductivity. Damage to SCs will likely cause faulty neuronal maintenance or demyelination and reduces axonal conductivity [1]. During peripheral nervous system regeneration, SCs can express various types of neurotrophic factors and adhesion molecules that support axonal regrowth and myelin sheath reconstruction. Apoptosis of SCs may promote axonal 
degeneration by reducing the neurotrophic support for axons from SCs $[2,3]$. Unlike neurons, which are not endogenously replaced after injury, SCs proliferate immediately after injury and infiltrate the lesion site to myelinate [4]. The SCs ability to promote nerve regeneration has increased interest in cell transplantation therapy for nervous system repair. Several previous studies have demonstrated that SC transplantation post-spinal cord-injury induces remyelination, promotes axonal regeneration, and enhances functional recovery $[5,6]$.

The efficacy of such cell-based therapies depends greatly on transplanted cell survival [7, 8]. In rat models of contused spinal cord, the dramatic losses of implanted SCs via necrotic and apoptotic cell deaths occur largely 3 weeks post-implantation [9-11]. Therefore, proper intervention by strategies that limit necrosis and/or apoptosis is being considered to enhance overall transplanted cell survival. Disturbances in the normal redox state of cells can cause toxic effects by producing peroxides and free radicals that damage cell components, including proteins, lipids, and DNA.

The genus Ocimum (O.), collectively called basil, is a popular culinary and medicinal plant. $O$. gratissimum, of the Lamiaceae family, is a small shrub known as "scent leaf" in Africa and "Chit-Chan-Than" in Taiwan. Phytochemically, $O$. gratissimum contains a high quantity of essential oils $(3.2 \%-4.1 \%)$ ocimol, gratissimin, $\beta$-sitosterol, flavonoids, linolenic acid, and polyphenolic compounds [12-14]. A significant quantity of simple phenols and flavonoids, including catachin, caffeic acid, epicatechin, and rutin, have been discovered in aqueous Ocimum gratissimum extract (OGE) [14-17]. Our recent study has shown that OGE can effectively inhibit the apoptotic mitochondrial pathway and protect nearby cells from oxidative stress-induced cell damage in vitro [15] and in vivo [17, 18]. Furthermore, OGE significantly decreases stress-related proteins, including HSP70 and iNOS, in livers of $\mathrm{CCl}_{4}$-administrated rats [14], indicating the anti-oxidative capabilities of OGE. Moreover, OGE is an anti-depressant, sedative, and anxiolytic $[18,19]$.

This study aimed to examine the effect of direct $\mathrm{H}_{2} \mathrm{O}_{2}$ oxidative injury on Schwann RSC96 cell survival and whether and how OGE could modulate the RSC96 cell survival. We found that $\mathrm{H}_{2} \mathrm{O}_{2}$-induced oxidative stress promotes RSC96 cell apoptosis and OGE minimizes the cytotoxic effects of $\mathrm{H}_{2} \mathrm{O}_{2}$ by modulating the apoptotic mitochondrial pathway. Moreover, we investigated how OGE prevents $\mathrm{H}_{2} \mathrm{O}_{2}$-induced apoptotic cell death in RSC96 cells and elucidated the underlying molecular mechanisms.

\section{Methods and Materials}

\section{Preparation of $\boldsymbol{O}$. gratissimum extract}

The $O$. gratissimum leaves were harvested, washed in running water, and air-dried for 1 week to create a coarse powder. The powdered vegetal material (400 g) was homogenized with distilled water $(1000 \mathrm{~mL})$ using a polytron. The homogenate was incubated at $95^{\circ} \mathrm{C}$ for $1 \mathrm{~h}$ and filtered through a two-layer gauze. The filtrate was centrifuged at 20,000 $g, 4{ }^{\circ} \mathrm{C}$ for $15 \mathrm{~min}$ to remove insoluble pellets, and the supernatant was thereafter collected, lyophilized, and stored at $-20{ }^{\circ} \mathrm{C}$ until use. Before the assays, the extract powder (OGE) was dissolved at required concentrations. The total polyphenol content was analyzed according to Folin-Ciocalteau method [20, 21], and total flavonoid content was determined using the Lamaison method [22]. The final OGE was composed of $11.1 \%$ phenolic acid and $4.5 \%$ flavonoids, as quantitatively measured and indicated in our previous paper [14-17].

\section{Cell culture}

RSC96 cells were obtained from Bioresources Collection and Research Center and maintained in Dulbecco's Modified Eagle's Medium supplemented with 10\% v/v fetal bovine serum (Gibco BRL, Gaithersburg, MD, USA) and $100 \mu \mathrm{g} / \mathrm{mL}$ penicillin/streptomycin (Sigma-Aldrich Chemie, Munich, Germany) at $37{ }^{\circ} \mathrm{C}$ in a humidified atmosphere containing 5\% $\mathrm{CO}_{2}$. RSC96 cells were seeded in 24-well culture plates at an initial density of $2 \times 10^{5}$ cells $/ \mathrm{mL}$ and grown to approximately $80 \%$ confluence. Oxidative stress was induced using fresh $\mathrm{H}_{2} \mathrm{O}_{2}$. Cells were pretreated with OGE at indicated concentrations for $24 \mathrm{~h}$, and the medium containing $\mathrm{H}_{2} \mathrm{O}_{2}$ (final concentration at $5.6 \%$ ) was added and incubated for indicated amounts of time. After incubation, the cells were washed with phosphate-buffered saline (PBS; $25 \mathrm{mM}$ sodium phosphate, $150 \mathrm{mM} \mathrm{NaCl}, \mathrm{pH} 7.2$ ) and collected for subsequent analysis. For morphological analysis, the cells were observed for size and number changes under an inverted Microscope (Olympus Corp., Japan) at $100 \times$ magnification.

\section{MTT assay}

Cell viability was determined using MTT assay. RSC96 cells were exposed to $\mathrm{H}_{2} \mathrm{O}_{2}$ or with or without test sample pretreatments (OGE). To determine the hydrogen peroxide cytotoxicity, RSC96 cells were treated with five $\mathrm{H}_{2} \mathrm{O}_{2}$ concentrations $(0,100,200,300$, and $400 \mu \mathrm{M})$, according to our pilot study. The $300 \mu \mathrm{M}$ $\mathrm{H}_{2} \mathrm{O}_{2}$ caused over $30 \%$ cell death after 6 h compared with untreated control cells. Thus, $400 \mu \mathrm{M} \mathrm{H} \mathrm{H}_{2} \mathrm{O}_{2}$ 
concentration was deemed appropriate for subsequent experiments in this study. RSC96 cells were starved for $6 \mathrm{~h}$ and pretreated with various indicated concentrations of OGE for $24 \mathrm{~h}$ and treated with $\mathrm{H}_{2} \mathrm{O}_{2}$ for $24 \mathrm{~h}$. After treatments, the medium was removed, and RSC96 cells were incubated with 3-[4,5-dimethylthiazol-2-yl]-2,5diphenyltetrazolium bromide (MTT $0.5 \mu \mathrm{g} / \mathrm{mL}$ ) at 37 ${ }^{\circ} \mathrm{C}$ for $4 \mathrm{~h}$. The viable cell number was directly proportional to the production of formazan, which was dissolved in isopropanol and determined by measuring the absorbance at $570 \mathrm{~nm}$ using a microplate reader.

\section{Flow cytometry}

Cells were suspended in phosphate buffered saline (PBS, pH 7.4) and fixed with 75\% (v/v) ethanol at $-20{ }^{\circ} \mathrm{C}$ for $12-16 \mathrm{~h}$. After ethanol removal, the cells were washed with PBS and stained for $30 \mathrm{~min}$ with $0.005 \%$ propidium iodide (PI). Analysis was performed immediately in FACSCalibur flow cytometer and Cellquest software (Becton Dickinson, San Jose, CA).

\section{Reverse transcription (RT)-PCR}

Total RNA was isolated from cell specimens by the guanidinium thiocyanate-phenol method. The extract integrity was assessed by $1.5 \%$ agarose gel electrophoresis and RNA was visualized by ethidium bromide staining. The total amount of RNA was determined spectrophotometrically. For each experiment, the number of PCR cycles was titrated to avoid reaching the amplification plateau. 25 cycles of PCR was used for an internal control GAPDH, and 30 cycles for other selected genes. The cDNA was synthesized using $500 \mathrm{ng}$ of total RNA (Omniscript RT Kit, Qiagen). PCR was performed in an Eppendorf PCR machine with the following conditions: denaturation/polymerase activation at $95{ }^{\circ} \mathrm{C}$ for 5 min, followed by the indicated cycles of $95^{\circ} \mathrm{C}$ for $15 \mathrm{~s}$, $50{ }^{\circ} \mathrm{C}$ for $20 \mathrm{~s}$, and $72{ }^{\circ} \mathrm{C}$ for $30 \mathrm{~s}$. The $20 \mu \mathrm{L}$ final reaction volume consisted of a pre-made reaction mix containing $5 \mathrm{pM}$ of each primer and $1 \mu \mathrm{L}$ cDNA in water. The following mouse targets were amplified using the indicated primer pairs: GAPDH, 5'-TCACTCAAGATTGTCAGCAA-3' and 5'-AGATC CACGACGGACACATT-3' (307 bp fragment 476-783, NCBI Reference Sequence: XM_001476707.5); HSP70, 5'-ATGAAGGAGATCGCCGAGG-3' and 5'-GTCAA AGATGAGCACGTTG-3' (218 bp fragment 595-813, NCBI Reference Sequence: NM_005346.4); HSP72, 5'-CTGGGCACCACCTACTCCTG-3' and 5'CTCCTTCATCTTCGTCAGCA -3' (356 bp fragment 262-618, NCBI Reference Sequence: NM_010478.2).

\section{Western blot}

Cultured RSC96 cells were scraped and washed once with PBS. The cell suspension was spun down, and cell pellets were lysed for $30 \mathrm{~min}$ in the lysis buffer (50 mM Tris ( $\mathrm{pH} 7.5$ ), $0.5 \mathrm{M} \mathrm{NaCl}, 1.0 \mathrm{mM}$ EDTA (pH 7.5), 10\% glycerol, $1 \mathrm{mM}$ BME, $1 \%$ IGEPAL-630, and proteinase inhibitor cocktail (Roche, Mannheim, Germany)) and centrifuged at $12,000 \mathrm{~g}$ for $10 \mathrm{~min}$. The supernatants were removed and placed in new Eppendorf tubes for Western blot analysis. Proteins from the RSC96 cells were separated in 12\% gradient SDS-PAGE and transferred onto nitrocellulose membranes. Nonspecific protein binding was blocked in the blocking buffer at room temperature for $1 \mathrm{~h}(5 \%$ milk, $20 \mathrm{mM}$ Tris- $\mathrm{HCl}, \mathrm{pH}$ 7.6, $150 \mathrm{mM} \mathrm{NaCl}$, and $0.1 \%$ Tween 20). The membranes were incubated in $4{ }^{\circ} \mathrm{C}$ blocking buffer overnight with specific antibodies (1:1000) caspase-3, PI3K, and Bcl2 (BD Biosciences, San Jose, CA); and Bax and tubulin (Santa Cruz Biotechnology, Inc., Santa Cruz, CA). For repeated blotting, nitrocellulose membranes were stripped with restore Western blot stripping buffer (Pierce Biotechnology, Inc, Rockford, IL, USA) at room temperature for $30 \mathrm{~min}$. Densitometric analysis of immunoblots was performed using the AlphaImager 2200 digital imaging system (Digital Imaging System, CA, USA). Experiments were performed in triplicate.

\section{Statistical analysis}

Statistical differences were assessed using one-way ANOVA. $p<0.05$ was considered statistically significant. Student's t-test was used in two-group comparisons. Data are expressed as mean \pm SD .

\section{Results}

\section{OGE attenuates $\mathrm{H}_{2} \mathrm{O}_{2}$-induced cell death in RSC96 cells}

To examine the effects of OGE on $\mathrm{H}_{2} \mathrm{O}_{2}$-induced cell death, RSC96 cells were pretreated with 0, 50, 100, 150 , and $200 \mu \mathrm{g} / \mathrm{mL}$ of OGE and challenged with 0 , $100,200,300$, and $400 \mu \mathrm{M} \mathrm{H}_{2} \mathrm{O}_{2}$. The results showed that administration of $\mathrm{H}_{2} \mathrm{O}_{2}(200,300$, and $400 \mu \mathrm{M})$ significantly diminishes RSC96 cell viability (53\%, $32 \%$, and $23 \%$, respectively) (Fig. 1). However, OGE pretreatment (150 and $200 \mu \mathrm{g} / \mathrm{mL})$ significantly elevates cell viability by approximately $62 \%$ or $66 \%$, respectively. Treatment with various OGE concentrations without the $\mathrm{H}_{2} \mathrm{O}_{2}$ challenge did not affect cell viability. The data therefore indicated that OGE pretreatment enhances the viability of cells affected by $\mathrm{H}_{2} \mathrm{O}_{2}$ challenge in a dose-dependent manner; moreover, OGE can protect RSC96 cells from $\mathrm{H}_{2} \mathrm{O}_{2}$-induced cell death. 


\section{OGE inhibits cell cycle transition}

Effect of OGE on cell proliferation was determined via cell cycle analysis using flow cytometry. RSC96 cells challenged with $300 \mu \mathrm{M} \mathrm{H}_{2} \mathrm{O}_{2}$ showed a higher (43\%) sub-G1 population compared with the untreated control group (1\%), indicating an accumulation in the sub-G1 population. However, OGE pretreatment (150 and $200 \mu \mathrm{g} / \mathrm{mL}$ ) significantly reduced the sub-G1 cells in a dose-dependent manner ( $7 \%$ and $8 \%$, respectively) and facilitated the cell cycle progression in RSC96 cells, as reflected by the reduced sub-G1 and increased G0/G1 populations (Fig. 2).

\section{OGE reverses the apoptotic protein expressions}

To observe whether OGE treatment could suppress caspase- 3 activation and arrest $\mathrm{H}_{2} \mathrm{O}_{2}$-induced apoptotic cell death in RSC96 cells, the changes in caspase- 3 levels and downstream PARP cleavage levels were examined. As shown in Fig. 3, an increase in caspase- 3 activity was observed in $\mathrm{H}_{2} \mathrm{O}_{2}$-treated cells. However, the phenomenon was attenuated upon OGE pretreatment. Moreover, the Bcl-2 protein expression level was significantly decreased and Bax protein expression level was

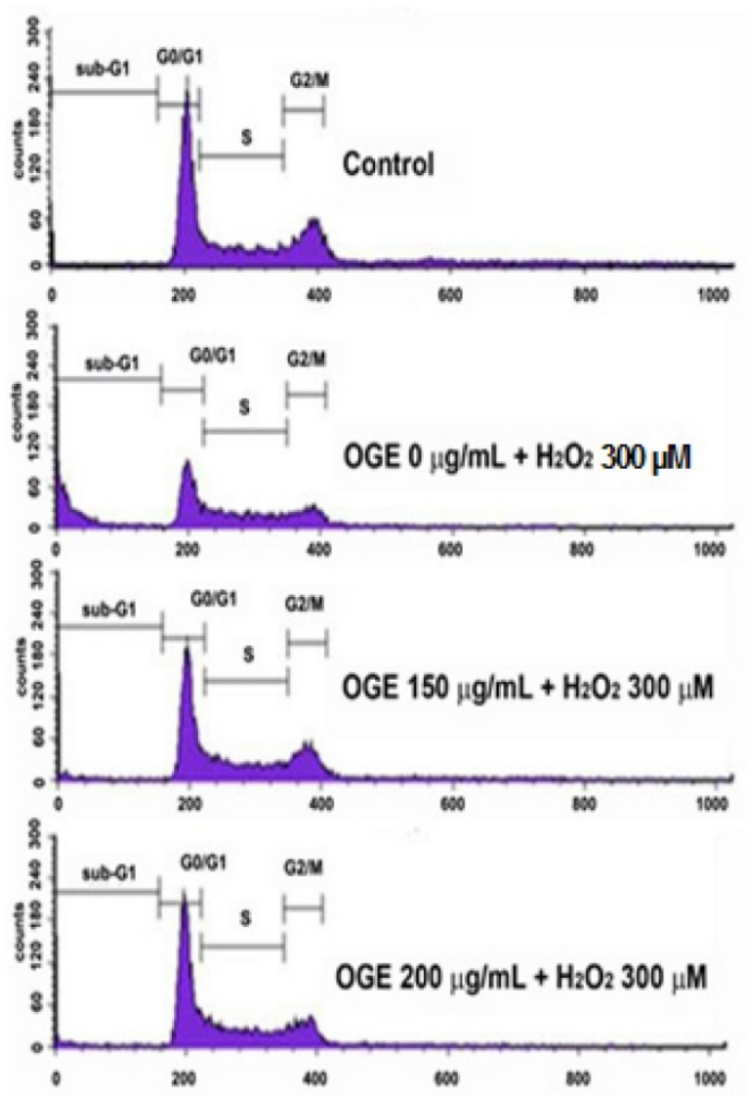

significantly increased in the $\mathrm{H}_{2} \mathrm{O}_{2}$-treated group compared with the untreated control group. Treatment with OGE significantly attenuated the effects of $\mathrm{H}_{2} \mathrm{O}_{2}$ on the expression levels of the two proteins. Adding OGE normalized the Bcl-2 and Bax levels in all conditions of $\mathrm{H}_{2} \mathrm{O}_{2}$ toxicity (Fig. 3 .

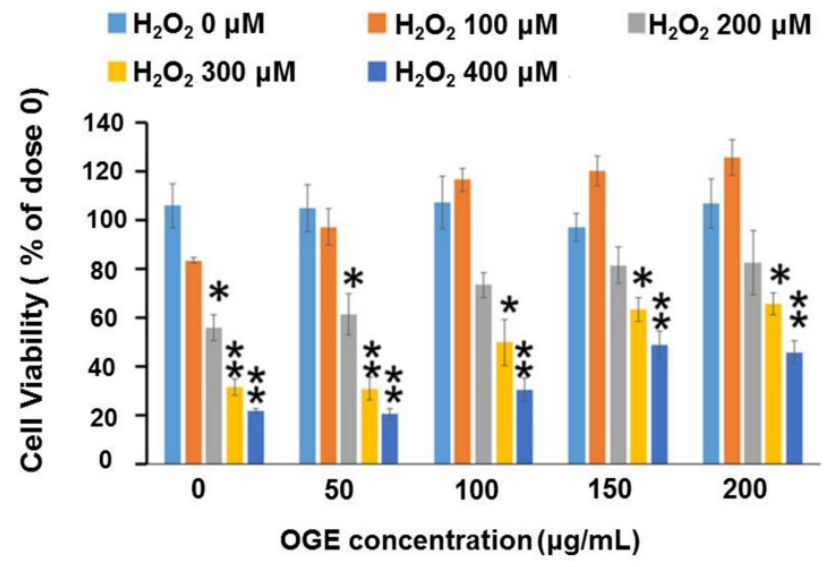

Figure 1. Effects of OGE on $\mathrm{H}_{2} \mathrm{O}_{2}$-induced cytotoxicity in RSC96 cells. The RSC96 cells were pretreated with OGE $(0,50,100,150$, and $200 \mu \mathrm{g} / \mathrm{mL})$ and then exposed to $\mathrm{H}_{2} \mathrm{O}_{2}(0,100,200,300$, and $400 \mu \mathrm{M})$. The cell viability was estimated using MTT assay. The results are expressed in percentage of untreated cells. Data are means \pm S.E. $(n=3) . * p<0.05$ indicates significant difference compared with the untreated group. ${ }^{*} p<0.01$ indicates significant difference compared with the untreated group.

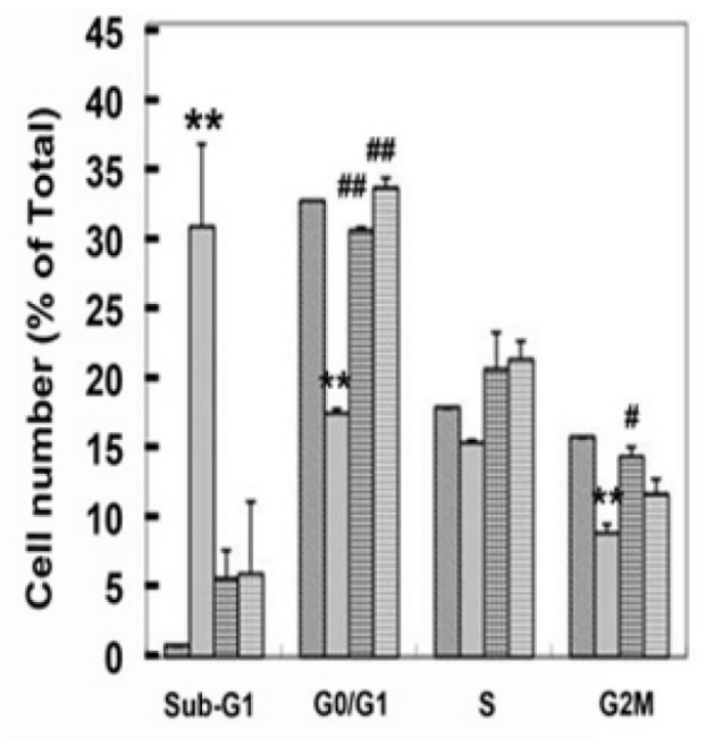

Figure 2. Effects of OGE on the cell cycle distribution in $\mathrm{H}_{2} \mathrm{O}_{2}$-treated cells. RSC 96 cells were pretreated with 150 and $200 \mu \mathrm{gg} / \mathrm{mL} \mathrm{OGE}$ for $24 \mathrm{~h}$ and challenged with $300 \mu \mathrm{M} \mathrm{H}_{2} \mathrm{O}_{2}$ for $12 \mathrm{~h}$. Data are means \pm S.E. $(n=3)$. ${ }^{*} p<0.01$ indicates significant difference compared with the control group; \#p<0.05 and \#\# $<0.01$ indicate significant compared with the $\mathrm{H}_{2} \mathrm{O}_{2}$ group 


\section{Protective effects of OGE is associated with PI3K- and ERK-independent signaling pathways}

RSC96 cells were exposed to specific PI3K and ERK inhibitors to identify the potential role of PI3K/ERK survival signaling cascades in the OGE-established protection against $\mathrm{H}_{2} \mathrm{O}_{2}$ toxicity in SCs. Upon MTT assay, the administration of PI3K and ERK inhibitors did not interfere in the cytoprotection of OGE against $\mathrm{H}_{2} \mathrm{O}_{2}$ toxicity in RSC96 cells (Fig. 4). Therefore, the enhanced cell survival by OGE is not dependent on PI3K- and ERK signaling pathways.

\section{HSP70 expression plays a compensative protection against $\mathrm{H}_{2} \mathrm{O}_{2}$-induced oxidative stress}

Induced expression or overexpression of Hsp70 can inhibit caspase activation by directly interacting with caspases [23, 24]; moreover, the protective effect of Hsp72 occurs upstream of the mitochondria [25]. To determine whether OGE administration has a stress-ameliorative effect, RSC96 cells were incubated in OGE and then exposed to $\mathrm{H}_{2} \mathrm{O}_{2}(300 \mu \mathrm{M})$ for $8 \mathrm{~h}$. The HSP70 and HSP72 expression levels were determined post $-\mathrm{H}_{2} \mathrm{O}_{2}$ treatment: the $\mathrm{H}_{2} \mathrm{O}_{2}$ challenge increased the HSP70 and HSP72 mRNA levels (Fig. 5), indicating the development of a compensative mechanism against $\mathrm{H}_{2} \mathrm{O}_{2}$-induced stress. However, OGE treatment resulted in a dose-dependent reduction of HSP70 and HSP72 mRNA levels due to oxidative stress suppression and reduction of the associated compensative HSP70 and HSP72 mechanism.

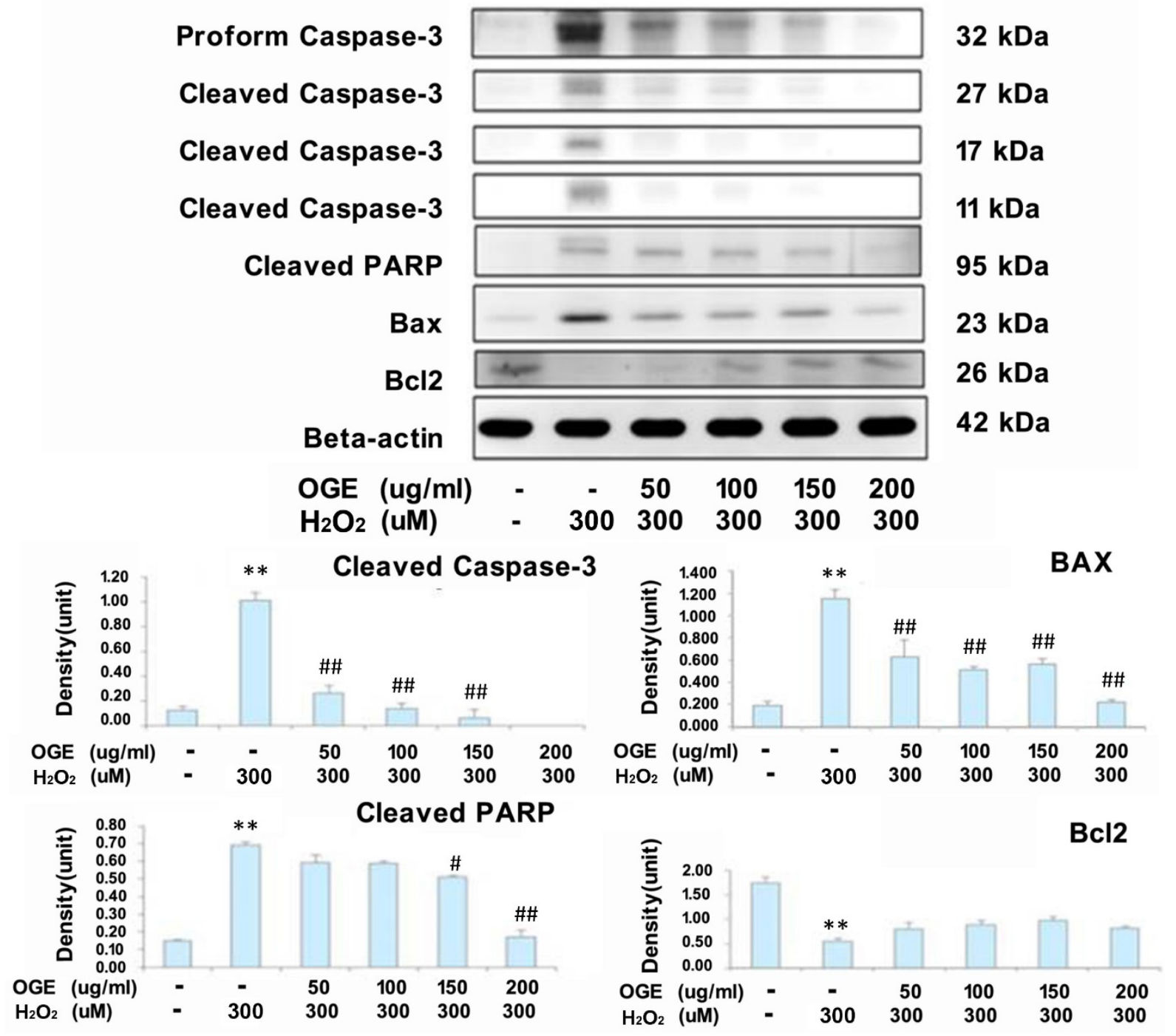

Figure 3. Effects of OGE on the expression levels of apoptosis-related proteins. The cells were pretreated with different OGE concentrations and then treated with $\mathrm{H}_{2} \mathrm{O}_{2}$ for $24 \mathrm{~h}$. The protein levels of cleavage caspase-3, PARP, Bax, and $\mathrm{Bcl}-2$ were measured using Western blot, and the statistical analysis ( $\mathrm{n}=3$ ) are presented in the panels below. Data are presented in means \pm S.E. $(n=3) . * * p<0.01$ indicates significant difference compared with the untreated control group. \#p<0.05 and $\#$ \# $<0.01$ indicate significant difference compared with the $\mathrm{H}_{2} \mathrm{O}_{2}$-treated group. 

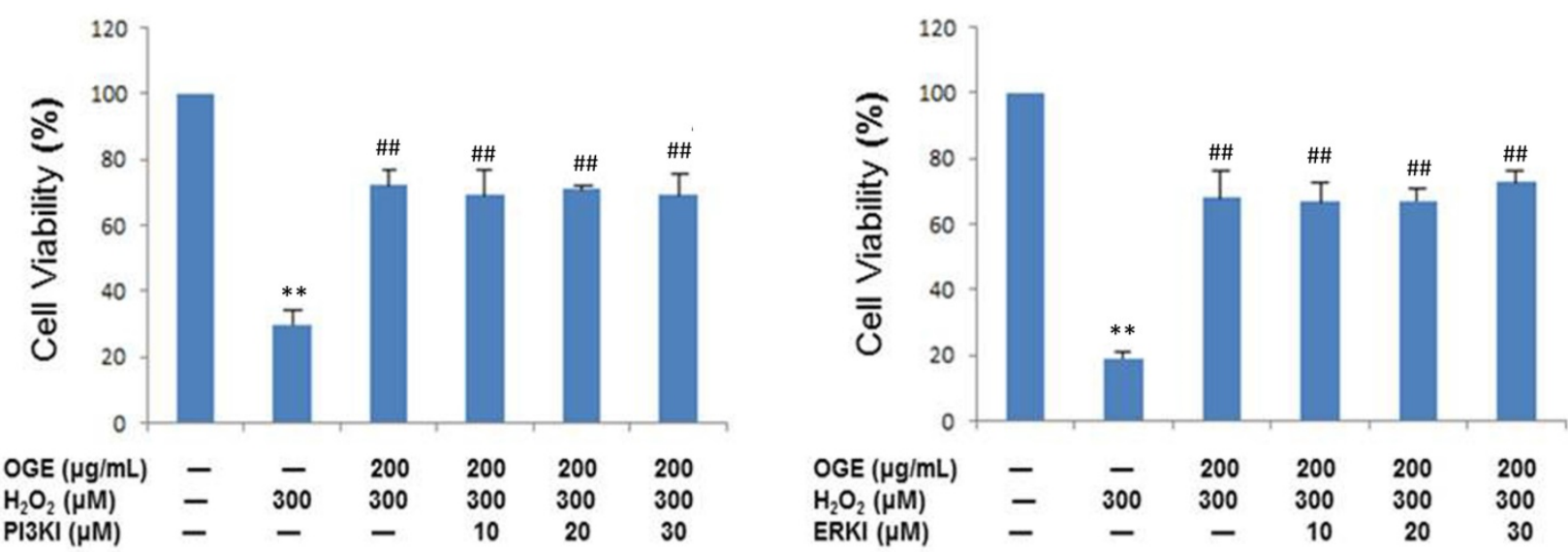

Figure 4. OGE enhances cell viability in the $\mathrm{PI} 3 \mathrm{~K}$ - and ERK-independent signaling pathways. The $\mathrm{RSCs}$ cells were treated with $\mathrm{H}_{2} \mathrm{O}_{2}$, $\mathrm{OGE}$, and one inhibitor ( $\mathrm{PI} 3 \mathrm{~K}$ and ERK). The cell viability was measured using MTT assay. The untreated cells were designated as control. The results were expressed as percentage of the untreated cells. Data are means \pm S.E. $(n=3) . * *<0.01$ indicates significant difference compared with the untreated control group. \#\# $<0.01$ indicates significant difference compared with the $\mathrm{H}_{2} \mathrm{O}_{2}$-treated group.

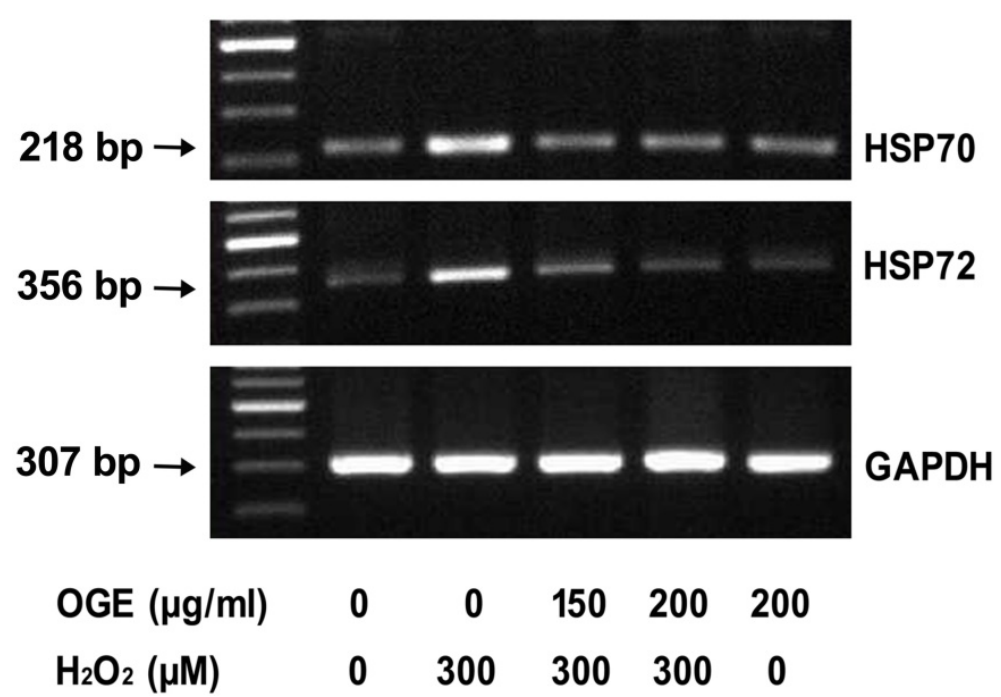

Figure 5. The HSP70 and HSP72 expressions in $\mathrm{H}_{2} \mathrm{O}_{2}$-treated RSC cells. RSC96 cells were pretreated with different OGE concentrations for $24 \mathrm{~h}$ and challenged with $300 \mu \mathrm{M} \mathrm{H}_{2} \mathrm{O}_{2}$ for $24 \mathrm{~h}$. The expressions HSP70, HSP72 and GAPDH were detected using RT-PCR analysis.

\section{Discussion}

Oxidative stress, which is characterized by overwhelming ROS, is among the mechanisms that induce cell apoptosis and is believed to cause neurodegenerative diseases. In neuronal cells, ROS results in membrane lipid peroxidation, protein nitration, and DNA degradation, all of which are associated with apoptosis [26]. Among the ROS stress mediators, $\mathrm{H}_{2} \mathrm{O}_{2}$ plays a pivotal role because it is generated from nearly all sources of oxidative stress and diffuses freely in and out of cells and tissues [27]. Schwann cells are exposed to various oxidative stress-mediated processes during nerve repair [28, 29]. Our results showed that $\mathrm{H}_{2} \mathrm{O}_{2}$ could induce cellular apoptosis in RSC96 cells.

Flow cytometry analysis showed that OGE pretreatment attenuates $\mathrm{H}_{2} \mathrm{O}_{2}$-induced sub-G1 phase accumulation, which may indicate cell apoptosis [28].
Moreover, OGE pretreatment reduces the level of cleaved caspase- 3 and only slightly affected the level of cleaved caspase-8, suggesting that the OGE mainly protects the mitochondrial pathway.

The caspases are cysteine proteases involved in the execution of cellular apoptosis in all most all cell types. They are expressed as pro-enzymes and are then activated following proteolytic cleavage. Cleaved caspases further cleave their target proteins as a part of the apoptosis-signaling mechanism. Caspase-3 is a major downstream caspase, activated by cleavage to produce at least a $12 \mathrm{kD}$ and a $17 \mathrm{kD}$ subunit. The un-cleaved pro-enzyme is expressed in various tissue types with different levels of expression. Caspase-3 is highly expressed in tissues with a greater tendency to apoptosis and the effects of caspase-3 expression on apoptosis are depended on the tissue type and the stimulus that induces apoptosis [29, 30]. 
In our results the increase in the level of pro-caspase expression shows that $\mathrm{H}_{2} \mathrm{O}_{2}$ treatment on RSC96 cells triggers the cells to be more inclined to apoptotic assault. Further increase in the levels in cleaved caspases also reveals the elevated apoptosis event in the RSC96 cells.

The mechanism of apoptosis is regulated by the Bcl-2 family of proteins, which includes the death agonists (e.g., Bax, Bak, and Bad) and antagonists (e.g., Bcl 22 and Bcl-xL) [31, 32]. Among these, Bax and Bcl-2 play key roles in regulating cell apoptosis. The balance between proapoptotic proteins, such as Bax, and antiapoptotic proteins, such as Bcl-2, is deemed critical in regulating apoptosis [33]. Our results indicated that OGE significantly enhances Bcl-2 levels in RSC96 cells and down-regulates the level of Bax, thereby suggesting that the antiapoptotic effects of OGE on RSC96 cells are correlated with Bcl-2 changes.

Upon studying, ERK pathway has been proven important in cell survival [15, 27]. Moreover, PI3K/Akt activation promotes cell survival via direct regulation of antiapoptotic $\mathrm{Bcl}-2$ and apoptotic proteins, including BAD, BCL-XL, and caspase-9. In previous papers [15], evidence showed that OGE activates $\mathrm{PI} 3 \mathrm{~K} / \mathrm{Akt}$ and can protect $\mathrm{H} 9 \mathrm{c} 2$ cells from $\mathrm{H}_{2} \mathrm{O}_{2}$-induced cell death. The PI3K and ERK inhibitors showed not much effect on the OGE mediated reduction of RSC96 cell death. Therefore the results suggests that either OGE competitively enhances the activation of PI3K and ERK or acts on other survival factors downstream to compensate the loss of PI3K and ERK activation.

Hsp70 protects SCs against apoptotic death from both $\mathrm{H}_{2} \mathrm{O}_{2}$ and serum withdrawal [34]. When ROS stress exceeds a threshold level, the preexisting antioxidant pathways may be complemented by cytoprotective mechanisms represented by heat shock proteins (HSPs) [35]. To test this hypothesis, we analyzed the HSP70/HSP72 expressions and found that they can be induced in $\mathrm{H}_{2} \mathrm{O}_{2}$-challenged RSC96 cells, suggesting that HSP70/HSP72 cause a complementary protective mechanism in RSC96 cells. OGE did not provide additional HSP70/HSP72 expressions, and we speculate that the reduced oxidative stress due to OGE treatment triggered the decrease in HSP70/HSP72 expressions however further studies should be performed to confirm such understanding.

In conclusion, OGE pretreatment prevents RSC96-cell apoptosis against oxidative stress in a dose-dependent manner. Cell transplantation of SCs is a promising modality for promoting neuronal survival and neural regeneration in spinal cord injury; therefore, these findings indicate that OGE could potentially confer neuroprotection to peripheral nerves by preserving SCs and diminishing oxidative stress-mediated injuries.

\section{Acknowledgement}

This work was supported by grants from the Ministry of Science and Technology, Republic of China (MOST 104-2320-B-039-032); the China Medical University Hospital, Taichung, Taiwan (DMR-106-030); and the China Medical University, Taichung, Taiwan (CMU104-S-41); as well as in part by Taiwan Ministry of Health and Welfare Clinical Trial and Research Center of Excellence (MOHW106-TDU-B-212-113004).

\section{Competing Interests}

The authors have declared that no competing interest exists.

\section{References}

1. Luo X, Chen B, Zheng R, et al. Hydrogen peroxide induces apoptosis through the mitochondrial pathway in rat Schwann cells. Neurosci Lett. 2010; 485(1): 60-4.

2. Fukunaga M, Miyata S, Liu BF, et al. Methylglyoxal induces apoptosis rough activation of p38 MAPK in rat Schwann cells. Biochem Biophys Res Commun. 2004; 320(3): 689-95.

3. Eckersley L. Role of the Schwann cell in diabetic neuropathy. Int Rev Neurobiol. 2002; 50: 293-321.

4. Bresnahan JC. An electron-microscopic analysis of axonal alterations following blunt contusion of the spinal cord of the rhesus monkey (Macaca mulatta). J Neurol Sci.1978; 37(1-2): 59-82.

5. Takami T, Oudega M, Bates ML, et al. Schwann cell but not olfactory ensheathing glia transplants improve hindlimb locomotor performance in the moderately contused adult rat thoracic spinal cord. J Neurosci. 2002; 22(15): 6670-81.

6. Akiyama Y, Lankford $\mathrm{K}$, Radtke $\mathrm{C}$, et al. Remyelination of spinal cord axons by olfactory ensheathing cells and Schwann cells derived from a transgenic rat expressing alkaline phosphatase marker gene. Neuron Glia Biol. 2004; 1(1): 47-55.

7. Hill CE, Guller Y, Raffa SJ, et al. A calpain inhibitor enhances the survival of Schwann cells in vitro and after transplantation into the injured spinal cord. J Neurotrauma. 2010; 27(9): 1685-95.

8. Patel V, Joseph G, Patel A, et al. Suspension matrices for improved Schwann-cell survival after implantation into the injured rat spinal cord. J Neurotrauma. 2010; 27(5): 789-801.

9. Pearse DD, Sanchez AR, Pereira FC, et al. Transplantation of Schwann cells and/or olfactory ensheathing glia into the contused spinal cord: Survival, migration, axon association, and functional recovery. Glia. 2007; 55(9): 976-1000.

10. Hill CE, Moon LD, Wood PM, et al. Labeled Schwann cell transplantation: cell loss, host Schwann cell replacement, and strategies to enhance survival. Glia 2006; 53(3) : 338-43.

11. Hill CE, Hurtado A, Blits B, et al. Early necrosis and apoptosis of Schwann cells transplanted into the injured rat spinal cord. Eur J Neurosci. 2007; 26(6): 1433-45.

12. Vieira RF, Grayer RJ, Paton A, et al. Genetic diversity of Ocimum gratissimum L. based on volatile oil constituents, flavonoids and RAPD markers. Biochem Syst Ecol. 2001; 29(3): 287-304

13. Bora KS, Shri $\mathrm{R}$ and Monga J. Cerebroprotective effect of Ocimum gratissimum against focal ischemia and reperfusion-induced cerebral injury. Pharm Biol. 2011; 49(2): 175-81.

14. Chiu CC, Huang CY, Chen TY, et al. Beneficial Effects of Ocimum gratissimum Aqueous Extract on Rats with $\mathrm{CCl}_{4}$ - Induced Acute Liver Injury. Evid Based Complement Alternat Med. 2012; 2012:736752.

15. Lee MJ, Chen HM, Tzang BS et al. Ocimum gratissimum Aqueous Extract Protects $\mathrm{H} 9 \mathrm{c} 2$ Myocardiac Cells from $\mathrm{H}_{2} \mathrm{O}_{2}$-Induced Cell Apoptosis through Akt Signalling. Evid Based Complement Alternat Med. 2011; 2011: 578060.

16. Chen HM, Lee MJ, Kuo CY, et al. Ocimum gratissimum Aqueous Extract nduces Apoptotic Signalling in Lung Adenocarcinoma Cell A549. Evid Based Complement Alternat Med. 2011; 2011: 739093.

17. Li PC, Chiu YW, Lin YM, et al. Herbal Supplement Ameliorates Cardiac Hypertrophy in Rats with $\mathrm{CCl}_{4}$-Induced Liver Cirrhosis. Evid Based Complement Alternat Med. 2012; 2012: 139045. 
18. Di Stasi LC, Oliveira GP, Carvalhaes MA, et al. Medicinal plants popularly used in the Brazilian Tropical Atlantic Forest. Fitoterapia, Fitoterapia. 2002; 73(1): 69-91.

19. Freire $\mathrm{CM}$, Marques $\mathrm{MO}$ and Costa M. Effects of seasonal variation on the central nervous system activity of Ocimum gratissimum L. essential oil. J Ethnopharmacol. 2006; 105(1): 161-6.

20. Singleton VL and Rossi JA. Colorimetry of Total Phenolics with Phosphomolybdic-Phosphotungstic Acid Reagents. Am J Enol Vitic. 1965; 16(3): 144-58.

21. Ainsworth EA, and Gillespie KM. Estimation of total phenolic content and other oxidation substrates in plant tissues using Folin-Ciocalteu reagent. Nat Protoc. 2007; 2(4): 875-7.

22. Lamaison JL, Carnat A and Petitjean-Freytet C. Tannin content and inhibiting activity of elastase in Rosaceae. Ann Pharm Fr. 1990; 48(6): 335-40.

23. Luo X,Tao L, Lin P, et al. Extracellular heat shock protein 72 protects schwann cells from hydrogen peroxide-induced apoptosis. Journal of neuroscience research. 2012; 90(6): 1261- 9 .

24. Komarova EY, Afanasyeva EA, Bulatova MM, et al. Downstream caspases are novel targets for the antiapoptotic activity of the molecular chaperone hsp70. Cell Stress Chaperones. 2004; 9(3): 265-75.

25. Steel R, Doherty JP, Buzzard K, et al. Hsp72 inhibits apoptosis upstream of the mitochondria and not through interactions with Apaf-1. J Biol Chem. 2004; 279(49): 51490-9.

26. Park CJ, Park SA, Yoon TG, et al. Bupivacaine induces apoptosis via ROS in the Schwann cell line. J Dent Res. 2005;84(9): 852-7.

27. Barbouti A, Doulias PT, Nousis L, et al. DNA damage and apoptosis in hydrogen peroxide-exposed Jurkat cells: bolus addition versus continuous generation of $\mathrm{H}_{2} \mathrm{O}_{2}$. Free Radic Biol Med. 2002; 33(5): 691-702.

28. Bladier C, Wolvetang EJ, Hutchinson $\mathrm{P}$ et al. Response of a primary human fibroblast cell line to $\mathrm{H}_{2} \mathrm{O}_{2}$ : senescence-like growth arrest or apoptosis ? Cell Growth Differ. 1997; 8(5): 589-98.

29. Woo M, Hakem R, Soengas MS, et al. Essential contribution of caspase 3/CPP32 to apoptosis and its associated nuclear changes. Genes Dev. 1998; 12(6): 806-19.

30. Hague A, Eveson JW, MacFarlane M, et al. Caspase-3 expression is reduced, in the absence of cleavage, in terminally differentiated normal oral epithelium but is increased in oral squamous cell carcinomas and correlates with tumour stage. J Pathol. 2004; 204(2): 175-82.

31. Newton, K and Strasser A. The Bcl-2 family and cell death regulation. Curr Opin Genet Dev. 1998; 8(1): 68-75.

32. Soilu-Hänninen $\mathrm{M}$, Ekert $\mathrm{P}$, Bucci $\mathrm{T}$, et al. Nerve growth factor signaling through p75 induces apoptosis in Schwann cells via a Bcl-2-independent pathway. J Neurosci. 1999; 19(12): 4828-38.

33. Castorina A, Tiralongo A, Giunta S, et al. PACAP and VIP prevent apoptosis in schwannoma cells. Brain Res. 2008; 1241: 29-35.

34. Gupta S, Deepti A, Deegan S, et al. HSP72 protects cells from ER stress-induced apoptosis via enhancement of IRE1alpha-XBP1 signaling through a physical interaction. PLoS Biol. 2010; 8(7): e1000410.

35. Smolka MB, Zoppi CC, Alves AA, et al. HSP72 as a complementary protection against oxidative stress induced by exercise in the soleus muscle of rats. Am J Physiol Regul Integr Comp Physiol. 2000; 279(5): R1539-R45. 